\title{
Announcements and call for papers
}

\section{ASIS meetings 1984}

The thirteenth American Society for Information Science (ASIS) Mid-year Meeting will take place at Indiana University in Bloomington, Indiana, on 20-23 May 1984. The theme chosen for this conference is: "The Micro Revolution Implications for the Information Age".

Advances in miniaturized technologies, especially the silicon chip, have made automation of information handling less expensive and more available. Microcomputers and other examples of the proliferation of microprocessors have major ramifications for the post-industrial society. How can this revolution be understood, and how will it affect the information world? Participants in the 1984 ASIS Mid-year Meeting will explore facets and implications of the micro revolution and beyond. Authors are encouraged to address problems and opportunities which these developments provide for the creation, acquisition, storage, retrieval, and use of information.

The principal topics will be:

- Information generation and the micro revolution. What changes have been or are being made in the creative processes as researchers, authors, editors, and others exploit the powers of the micro? (Personal databases and search systems; the microcomputer as a research tool; word processing; the office of the future.)

- Social aspects of the micro revolution - The third wave. How has society changed with the advent of the micro? What changes can be anticipated with the greater availability and decentralization of computer power? (Home access to information; recreational use; cottage industry; information overload; psychological implications of a personal machine; social implications of decentralized knowledge.)

- Technological developments of the micro revolution. What equipment is available, how is it being used in information systems, and what can we expect in future developments? (Euipment evaluation; distributed processing; information processing technology-videodiscs, terminals, printers, microforms.)

- Information access and the micro revolution. How have micros affected the ways people and machines acquire, store, retrieve, and use information? (Artificial intelligence and development of user-friendly systems; micro interfaces to mainframe systems; improving access to information for "naïve" users; building a knowledge base for online information retrieval; software-make or buy?; elec- 
tronic mail and the electronic journal; graphics displays; microcomputers in teaching.)

The conference will take place on the Indiana University campus, using air-conditioned dormitories, dining facilities, and meeting rooms. Indiana University, Bloomington, and the surrounding southern Indiana area provide a blend of academic atmosphere and bucolic charm. Bloomington is easily reached on major highways or through connections at the Indianapolis or Chicago airports.

21-26 October 1984 are the dates set for the forty-seventh ASIS Annual Meeting in Philadelphia, Pennsylvania on the theme: "Challenges to an Information Society".

This meeting takes place near the end of 1984. Orwellian predictions are fulfilled or unfulfilled. An emerging information society predicts and defines new challenges for the remainder of the decade. Participants in the convention will consider these challenges. By 1990, what theory, research, technologies, techniques, issues, and policies will be realized? Authors are asked to discuss applications, practices, and major societal concerns emanating from current research and development, and to consider their impact at the following levels:

- The individual - e.g., work and life environment in an information-rich society, effects on behavior; computer facilitation of intellectual endeavors.

- The organization - e.g., reinventing the workplace; selection and training of the workforce; worker displacement.

- The society - e.g., freedom of speech and press; privacy; education and the computer; the future of hard copy.

- The world - e.g., knowledge as power; fairness and equity in an informationrich society; information-rich $v s$. information-poor.

Papers will be evaluated on the basis of: emphasis on future applications, current research and development, generalizable data, theoretic thrust, and policy concerns.

In order to receive additional instructions, notice of intent to submit must be received by 15 March 1984. Please send a one-page proposal describing ideas for presentation to: 1984 ASIS Convention, The Automated Office, 3401 Market Street, Philadelphia, PA 19104, USA. Manuscripts are due by 15 May 1984, and notification of acceptance will be sent 15 July 1984. Please include name, affiliation, mailing address, phone, and tentative title.

For further information concerning these two meetings, and in order to obtain application forms for attendance, please contact:

The American Society for Information Science

1010 Sixteenth Street NW

Washington, DC 20036

USA

Telephone (202) 659-3644 


\section{Announcement and call for papers}

\section{$3^{\mathrm{e}}$ Congrès-exposition international sur les banques de données Infodial/Videotex '84}

\section{Introduction}

The Infodial/Videotex '84 congress will be held from 17 to 21 September 1984. It will be organized jointly by the Groupement français des producteurs de bases et banques de données (the French Federation of Data Base Producers) and SICOB (Salon international d'informatique, télématique, communication, organisation du bureau et bureautique).

In 1984, Infodial/Videotex will cater for all the users of data bases and other online services, and more especially companies and small and medium-size businesses, the liberal professions, scientists and technicians-in a word, for all those decision makers who feel the need for adequate, reliable and readily accessible information.

\section{Program}

The program of Infodial/Videotex '84 will comprise:

- A series of conferences on the use of data bases and other online services as a decision-making tool, viewed in the light of different functional approaches. Particular emphasis will be placed on cheap access via telecommunications networks to information covering a wide field of different subjects (such as politics, science, economics, trade, technics and law), and offering all types of practical and operational data (facts, numerical data, bibliography).

- A series of conferences concerning the development prospects and possibilities offered by videotex via a mass of different in-house and external online services and products, of a practical or professional nature, and which videotex puts within the user's reach.

- Initiation sessions open to all those interested in making greater use of videotex online services and data bases. 
- An exhibition enabling congress delegates to discover, interrogate online or consult, data bases and the other online products and services offered by numerous French and foreign companies and institutions.

\section{Call for papers}

The Infodial/Videotex ' 84 congress provides a forum for discussion between present and future users of information and online services, data-base producers, service companies, host-computer companies, carriers and computer manufacturers. It is seeking offers of papers for its 1984 event.

These papers should provide concrete and practical examples of applications and uses of data bases and other online services-especially those based on videotex-which are available to the different types of users for which the congress caters, and, more especially:

- corporate managers, managerial and operational executives, lawyers, public accountants, consultants, financial analysts, bankers, and engineers specializing in marketing and corporate planning;

- professionals of the information industries who are interested in learning more about new possibilities of access to computerized information;

- all who are interested in specialist or practical information.

Papers should show the congress delegates what information and online services are all about, what they can be used for, and how they can be accessed. The topics selected will concern the four congress themes:

- economic and commercial applications,

- legal and fiscal applications,

- financial applications,

- scientific and technical applications.

\section{Procedure for offering papers}

The program committee invites all interested speakers to send in their proposals to the congress secretariat, in triplicate.

Each proposal should comprise:

- a front page, showing the title of the proposed paper, the name of the author, the name of any association, company or agency of which he/she is a member, and his/her address and telephone number;

- a summary of the proposed paper (at least 25 typewritten lines);

- a short biography of the author;

- the attached information form. 


\section{Publication of the papers}

The text of the papers will be published in the conference proceedings, which will be available from the opening of the congress. Speakers undertake to send the complete text of their papers to the congress secretariat before 30 June 1984 . The text, free of all copyright, should be preceded by a summary in the congress working languages (French and English).

\section{Congress attendance}

Speakers are admitted free of charge to their own sessions only. If they wish to attend the full congress, they are requested to pay the corresponding entry fee. Infodial regrets its inability to cover their travel and accommodation expenses. The papers shall last approximately twenty to thirty minutes. All necessary audiovisual aids are available on the spot. French and English will be used, with simultaneous interpretation.

\section{Organization and participation}

Chairmen of the organizing committee are Michel Henry and Max Hermieu. Program committee chairman is Marc Daubresse. The participants in the congress organization include industry federations representing French computer manufacturers, service companies and importers of office equipment (SFIB, SYNTEC, SNIMABI).

The Groupement français des producteurs de bases et banques de données is a non-profit-making association created in 1979 to meet the needs of information systems manufacturers. Three main aims dictate the policy of this Federation:

- the promotion and development of French data banks and data bases at a national and an international level;

- the organization and promotion of consultation and harmonization between data bank and data base manufacturers at a national level;

- discussion of problems of mutual interest to manufacturers in their relations with marketing organizations, users and governments.

SICOB, the International Trade Show for Data Processing, Telematics, Communications, Office Organization and Office Automation, is a yearly event which this year takes place in Paris on 19-28 September.

SICOB offers the visitor a complete overview of every aspect of modern corporate management tools over a display area of 88,700 square meters.

This third edition of the Infodial/Videotex congress and exhibition will be held at the Palais des Congrès, Paris, at the same time as Convention Informatique, Europe's leading software congress, and the SICOB Trade Show. Its program concerning the use of data bases will supplement the sessions of Convention Informatique. 
The SICOB-Infodial/Videotex exhibition, also at the Palais des Congrès, will group the leading European data-base producers and service companies, which will display their products and services to a public of users drawn from all the different social and economic sectors invited to the exhibition and congress. A shuttle service will be available between SICOB-Infodial/Videotex and the SICOB Trade Show, which will be held for the 35th consecutive year at the CNIT, Paris - La Défense, from 19 to 28 September.

Interested persons may fill in the form below (or a photocopy of this form) and send it to Infodial/Videotex, 4 Place de Valois, 75001 Paris, France; or, contact the organizers at telephone (1) 261-5242, telex $212597 \mathrm{f}$.

\section{Infodial/Videotex '84}

Surname $\ldots \ldots \ldots \ldots \ldots$ Forename(s)

Position/title .......... Firm or organization

Street address . . . . . . . . . PO Box

Postal code

Town

Country

$\square \quad$ intends to submit a paper.

$\square$ wishes to receive an exhibitor's application file for SICOB-Infodial/ Videotex.

$\square \quad$ wishes to receive further information on Infodial/Videotex '84. 


\section{Announcement and call for papers}

\section{EUSIDIC 1984 Annual Conference}

The EUSIDIC (European Association of Information Services) Annual Conference will take place in Baden, Austria (near Vienna), on 16-18 October 1984. "Information as an Exploitable Resource" is the theme which has been chosen for this event.

Papers dealing with the above-mentioned theme are invited from EUSIDIC members. The conference will bring together information users, vendors, producers, and policy makers - all of whom are trying to exploit the use of information in some way. Papers are acceptable for any of the following five sessions:

Exploiting information. Users of information explain their information requirements from both the management and the technical point of view; suppliers of information show how the market is progressing and how it can best be exploited.

Bibliographic vs. primary information. Data-base producers and users put forward the contrasting merits and futures of bibliographic, full-text and numeric information.

Information policy. National and international policy for telecommunications, markets and services; policy makers and users expose the details and problems.

Future hardware and software. What processors, storage, communications and specialized software will be designed and marketed in the future.

Friendly interfaces. Data input, graphics, user-friendly systems, videotex, expert systems and other 'friendly' hardware and software.

Papers will be presented in English, and a full paper should be made available to the Program Chairman at the conference.

Anyone wishing to contribute a paper should send details of the provisional title and a brief summary to the Program Chairman before 30 April 1984:

Anne Girard (Program Chairman)

Service de Documentation,

Institut Français du Pétrole

1-4 avenue de Bois-Préau

92506 Rueil-Malmaison

France 
EUSIDIC, formerly called the European Association of Scientific Information Dissemination Centers, was established in 1970. Its constitutionally stated purpose is "to promote the unimpeded and efficient flow of information in machinereadable form both within Europe and between Europe and the rest of the world". EUSIDIC membership comprises approximately 200 organizations from eighteen European nations, with associate members from numerous other countries (Australia, Brazil, Canada, Israel, Saudi Arabia, South Africa, and the United States of America). Member organizations include data-base producers, online information-retrieval services, intermediaries, users, publishers, libraries, hardware and software providers, professional associations etc. EUSIDIC is governed by a Council with members drawn from various European nations, and it sponsors working groups on specific topics of interest to its membership. EUSIDIC holds an Annual Conference each October at a location varying from year to year (recent locations have been in The Netherlands, Yugoslavia, Switzerland, Portugal, and France), and since 1982 has organized a Technical Meeting each spring in France. 


\section{Announcement and call for papers}

\section{Second International Congress on Computers in Science}

The Second International Conference on Computers in Science, sponsored by Science Magazine, in conjunction with Scherago Associates, will be held in Washington, DC, from 28 October through 1 November 1984. The conference will emphasize the use of the workstation for the scientist. There will be invited talks in a number of areas including

- biology workstations

- computer aided molecular design

- workstation hardware

- artificial intelligence

- data bases

- laboratory automation and robotics

- management of the electronic laboratory

In addition, there will be submitted poster talks, workshops in a number of areas, and a large vendor exhibition.

Prospective authors should send for an abstract form, registration and hotel information, to Ed Ruffing, Scherago Associates, 1515 Broadway, New York, NY 10036, USA; tel. (212) 730-1050.

Completed abstracts should be sent to the conference chairman, Dr. Stephen R. Heller, EPA, PM-218, Washington, DC 20460, USA; tel. (202) 382-2424. 

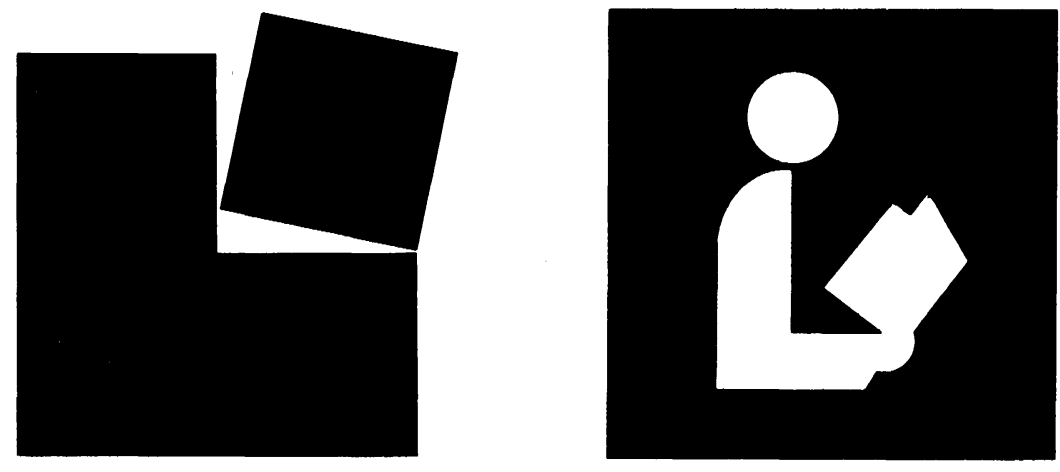

The official national library symbols of the United Kingdom (left) and the USA, now being widely promoted by the library communities in those two nations. 